\title{
BICIKLISTIČKI SAOBRAĆAJ U URBANIM SREDINAMA
}

Zorica Anđelković, dipl.građ.inž. ${ }^{1}$

Doc. dr Igor Jokanović, dipl.građ.inž. ${ }^{2}$

UDK: $625.711 .4: 711.4$

DOI: 10.14415/zbornikGFS28.10

Rezime: Biciklizam je pojam koji označava korišćenje bicikla, ali i bilo kojeg drugog prevoznog sredstva pokretanog isključivo ljudskom snagom. Razvijanje biciklističkog saobraćaja u urbanim sredinama podrazumeva izgradnju biciklističke infrastrukture, prilagođavanje ulica i ostale saobraćajne infrastrukture formi pogodnoj za biciklizam $i$ druge oblike kretanja (individualni motorni saobraćaj, javni prevoz, pešačenje), osiguranje odgovarajućeg budžeta $i$ sistematsko planiranje $i$ razvijanje održivog saobraćaja u gradovima. U okviru rada se prikazuju osnovne postavke i uslovi kao ulazni elementi za planiranje biciklističkog saobraćaja u urbanim sredinama, kao i programskoprojektni uslovi koje usmeravaju aktivnosti planera i projektanata urbanih saobraćajnica u vezi sa biciklistima.

Ključne reči: saobraćaj, biciklizam, planiranje, programsko-projektni uslovi, javni saobraćaj

\section{UVOD}

Bicikli su se pojavili u XIX veku, ali je tek početkom XX veka bicikl kao prevozno sredstvo postao rasprostranjen širom Evrope. Iako se pod pojmom biciklizma danas uglavnom podrazumeva sportsko i rekreativno korišćenje istog, u mnogim delovima sveta bicikl služi kao veoma čest, pa čak i uobičajen vid prevoza. Zbog relativno jeftine izrade i dostupnosti bicikl je danas najrasprostranjenije sredstvo prevoza, pa se pretpostavlja da danas u svetu postoji preko milijardu bicikala [6].Razvijati biciklistički saobraćaj u urbanim sredinama znači izgraditi biciklističku infrastrukturu, prilagoditi ulice i saobraćajnu infrastrukturu formi pogodnoj za biciklizam i druge oblike kretanja (individualni motorni saobraćaj, javni prevoz, pešačenje), osigurati odgovarajući budžet i sistematski planirati i razvijati održivi saobraćaj u gradovima. Biciklistima je potrebno omogućiti dobro povezivanje s ostatkom saobraćajne mreže i vraćanje na početnu tačku putovanja. Razvoj biciklističkog saobraćaja se postiže isprobanim i uhodanim strategijama: uvođenje javnih bicikala, izgradnja širokih, kvalitetnih i bezbednih

\footnotetext{
1 Javno urbanističko preduzeće Urbanizam Stara Pazova, Svetosavska 11/3, Stara Pazova, Republika Srbija, e-mail: zorica_andjelkovic@hotmail.com

2 Univerzitet u Novom Sadu, Građevinski fakultet Subotica, Kozaračka 2a, Subotica, Republika Srbija, e-mail: jokanovici@gf.uns.ac.rs
} 
biciklističkih staza, uvođenje sigurnih parkirališta za bicikle, informisanje i obrazovanje svih učesnika u saobraćaju, itd.

Cilj ovog rada je da se istaknu postavke i uslovi koji definišu potrebu za planiranjem biciklističkog saobraćaja u urbanim sredinama, kao i programsko-projektni uslovi koji definišu aktivnosti planera i projektanata urbanih saobraćajnica. Istovremeno će se dati prikaz relevantne analize obavljene za području naselja Banovci u opštini Stara Pazova.

\section{OSNOVNE KARAKTERISTIKE BICIKLISTIČKOG SAOBRAĆAJA}

Od kraja XIX veka biciklizam je postao uobičajen način prevoza, naročito na kraćim relacijama. Već u to vreme se pojavio problem zajedničkog korišćenja saobraćajnica od strane biciklista, konjskih zaprega i pešaka. Razvojem automobilske industrije i porastom stepena motorizacije taj problem se uvećavao. Danas se iz raznih razloga (zdravstvenih, ekoloških, finansijskih i dr) nastoji popularizovati korišćenje bicikala pri čemu se kao jedan od najvažnijih preduslova postavlja postojanje adekvatne infrastrukture za bezbedno odvijanje biciklističkog saobraćaja u urbanim sredinama. Pored pešačenja, vožnja biciklom predstavlja najzdraviji i ekološki najprihvatljiviji vid putovanja. Bicikl kao prevozno sredstvo pruža vozačima veliku slobodu u izboru željene, optimalne i najkraće putanje, mogućnost da putovanje obave po sistemu "od vrata do vrata", kao i prolazak kroz zone koje su zabranjene za sve ostale vidove saobraćaja. Bicikl zbog svojih gabarita zauzima manje prostora, pa njegova upotreba umanjuje potrebe za parking površinama. Zbog svojih karakteristika i fleksibilnosti bicikl je kao prevozno sredstvo veoma efikasan i u situacijama kada se na uličnoj mreži jave zastoji. Iz tih razloga biciklistički saobraćaj u mnogim gradovima Evrope predstavlja jedan od osnovnih vidova prevoza u cilju zadovoljavanja mobilnosti $\mathrm{i}$ jednu od polaznih tačaka strategija održivog razvoja saobraćaja $[5,6]$.

Prosečan stanovnik grada u Evropskoj uniji obavi oko tri putovanja na dan, a polovina tih putovanja je kraća od tri kilometra. S druge strane, polovina svih putovanja automobilom je kraća od šest kilometara, čime se jasno iskazuje potencijal korišćenja bicikla kao zamene za automobilska putovanja. Veliki broj gradova u Evropi je već odavno prepoznao prednosti biciklističkog saobraćaja za gradska putovanja [6]. Najbolji primer za biciklistički saobraćaj u gradovima je Holandija gde na oko 17 miliona stanovnika postoji oko 18 miliona bicikala. U Amsterdamu se gotovo pola miliona bicikala svakodnevno koristi. Iskustva iz čitave Evrope ukazuju na povezanost kvalitetne infrastrukture i obima biciklističkog saobraćaja. Kao primer pozitivnog pristupa biciklističkom saobraćaju u urbanim sredinama kod nas se može izdvojiti grad Novi Sad koji ima zadovoljavajući biciklističku infrastrukturu.

Bicikl u poređenju sa motornim vozilom poseduje niz prednosti:

- $\quad$ korišćenje obnovljive energije;

- ekonomska isplativost;

- ne postoje štetne emisije (buka, štetni gasovi, otpadne materije i dr);

- $\quad$ smanjenje potreba za infrastrukturom (kretanje i parkiranje);

- $\quad$ smanjenje rizika od zagušenja u saobraćaju;

- uglavnom besplatno parkiranje;

- manji zahtevi za održavanjem infrastrukture. 
Kao negativne strane biciklističkog saobraćaja moguće je navesti sledeće:

- $\quad$ povećan rizik kod udesa, pogotovo prilikom sudara sa motornim vozilom;

- duže vreme putovanja;

- nedostatak zaštite od vremenskih nepogoda;

- nemogućnost prevoza više putnika.

Osim korišćenja bicikla za potrebe savlađivanja rastojanja, od 80-tih godina prošlog veka u Evropi i Sjedinjenim Američkim Državama bicikl je počeo da se koristi i kao prevozno sredstvo u svrhu rekreacije i realizacije kraćih i dužih turističkih putovanja.

Ovo je ubrzo dovelo do razvoja novog vida turizma pod nazivom cikloturizam (Sl. 1), pogotovo u poslednjoj deceniji.

Iz tog razloga je u Evropi uspostavljena i mreža međunarodnih biciklističkih EuroVelo ruta radi stvaranja infrastrukturne osnove za razvoj cikloturizma, ali i sa ciljem podrške stvaranju održive Trans-evropske mreže saobraćajnica.

Planiranu mrežu čini 14 biciklističkih koridorskih ruta ukupne dužine oko 70.000 km (do sada realizovano oko 45.000 km) [11]. Kroz našu zemlju prolazi Dunavska biciklistička ruta (EuroVelo 6) i Istočno-evropska ruta (EuroVelo 11).
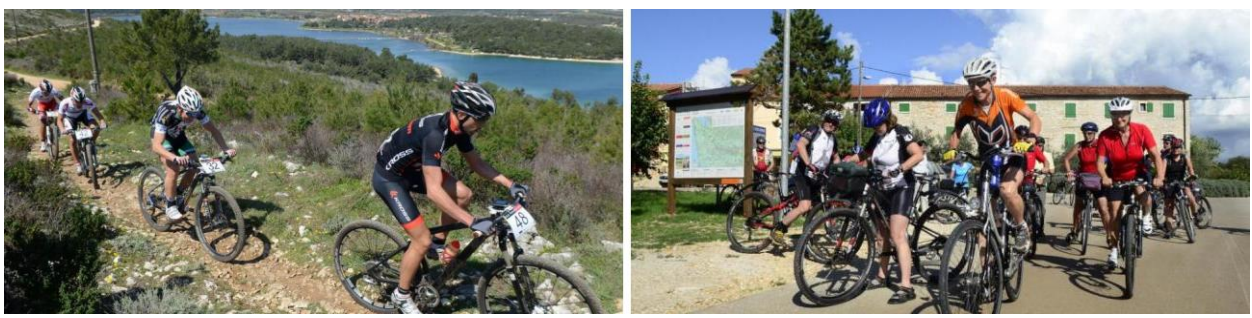

Slika 1. Primeri cikloturizma [Internet]

Još jedna od karakteristika modernog biciklističkog saobraćaja je pojava "bike sharing" sistema, odnosno sistema javnih bicikala kao jedne od mera za realizaciju strategije održive mobilnosti u većini gradova sveta (Sl. 2).

Tako je sistem javnih bicikala iz interesantnog eksperimenta izrastao u jednu od vodećih usluga javnog transporta u velikim gradovima poput Pariza i Londona.

Bike sharing sistemi u Parizu, Barseloni i Lionu se smatraju najboljim sistemima u primeni.

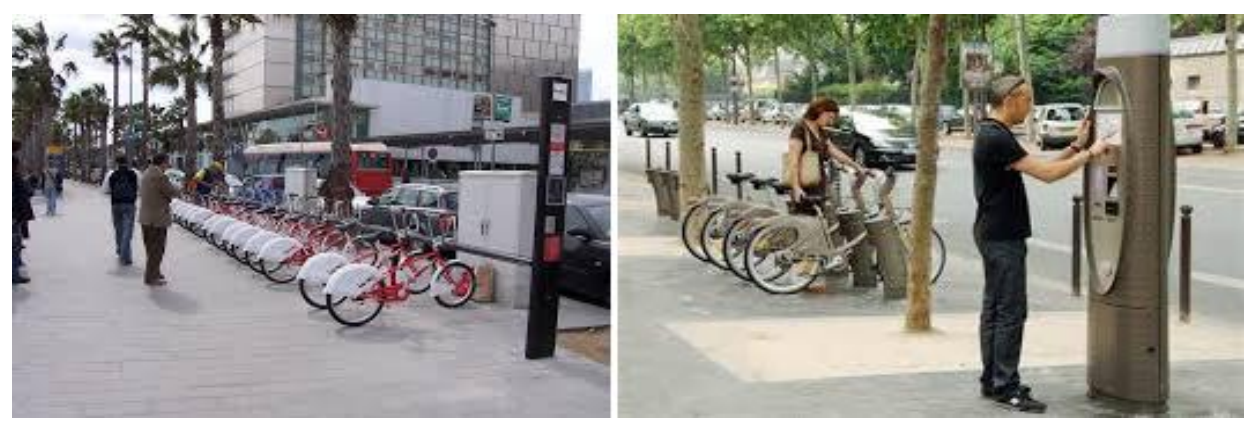

Slika 2. Sistemi javnih bicikala [Internet] 


\section{PROGRAMSKI I PROJEKTNI USLOVI}

Opšti programski uslovi obuhvataju polazne planerske postavke kojima se definišu vrste i tipovi saobraćajnica u gradskom području saglasno funkcionalnoj klasifikaciji. Oni podrazumevaju opšte uslove proistekle iz različitih kriterijuma, počev od urbanističkih funkcija saobraćajnice do zahteva pojedinačnih vidova prevoza uz neophodnu koordinaciju za svaki potez i/ili deonicu putne mreže u gradskom području.

U skladu sa urbanističkom funkcijom saobraćajnica, biciklističke staze se mogu pojaviti u okviru saobraćajnica primarne (gradske) putne mreže, i to najčešće u regulaciji sabirnih ulica, ali i mnogo češće u okviru sekundarne (lokalne) putne mreže.

Prema opštim programskim uslovima za biciklistički saobraćaj, karakteristična je potreba uređenja poprečnog i podužnog vođenja u odnosu na kretanje drugih vidova prevoza sa posebnim naglaskom na nestabilnost biciklista pri malim brzinama kretanja. U okviru funkcionalno najniže kategorije putne mreže (pristupne ulice), kretanje biciklista je slobodno na svim kolovoznim površinama uz poštovanje opštih pravila vožnje ili prema regulativi i merama za umirenje saobraćaja. Kod ostalih funkcionalnih kategorija (sabirne ulice, gradske magistrale) stepen izdvajanja biciklista (biciklistička traka obeležena na kolovozu ili biciklistička staza izvan kolovoza) zavisi od inteziteta tokova motornih vozila i/ili biciklista. Na gradskim autoputevima se biciklistički saobraćaj vodi nezavisno izvan regulacionih linija saobraćajnice uz denivelaciju poprečnih kretanja biciklista u odnosu na gradski autoput $[1,2]$.

Projektni uslovi čine osnovu za projektovanje saobraćajnica u gradovima i obuhvataju statičke karakteristike merodavnih vozila, osnovne elemente biciklističkog i pešačkog saobraćaja i merodavne pokazatelje od uticaja na dimenzionisanje geometrijskih elemenata, pre svega u poprečnom profilu saobraćajnice.

Pored vozila koja koriste i vangradsku putnu mrežu kao posledica kontinuiteta kretanja na međugradskim relacijama, na gradskoj putnoj mreži se pojavljuju i posebni tipovi vozila primereni gradskim ili prigradskim relacijama bilo kao posledica krajnjeg dometa (bicikli) ili specijalizacije za potrebe gradskih funkcija (prevoz robe, javni prevoz, iznošenje smeća, snabdevanje i sl). Bicikl se kao merodavno vozilo primenjuje za dimenzionisanje posebnih biciklističkih traka ili staza, kao i kod parkirališta za bicikle u gradskom području (Sl. 3). Minimalan poluprečnik okretanja za bicikliste iznosi $3,00 \mathrm{~m}$. Nestabilnost biciklista pri malim brzinama kretanja uslovljava potrebu za relativno širokim dinamičkim gabaritom $[1,2]$.

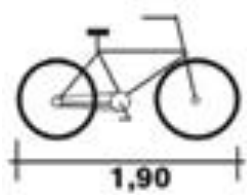

dužina: $1,90 \mathrm{~m}$ širina: $0,60 \mathrm{~m}$ visina: $1,00 \mathrm{~m}$

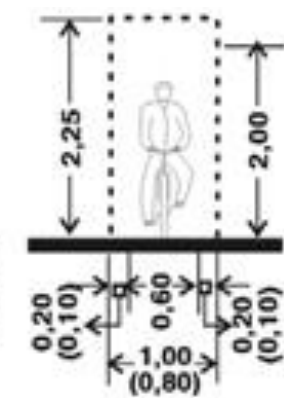

Slika 3. Statičke karakteristike bicikla i jedinični saobraćajni profil za biciklistički saobraćaj [1,2] 


\section{PROJEKTNI ELEMENTI BICIKLISTIČKIH STAZA}

Projektovanje biciklističkih staza se sastoji od izbora i dimenzionisanja projektnih elemenata, što obuhvata izbor i dimenzionisanje elemenata poprečnog profila (funkcionalnih i konstruktivnih), ispunjavanje zahteva saobraćajnog i slobodnog profila, kao i projektnih elemenata situacionog i nivelacionog plana. Prilikom planiranja i projektovanja biciklističkih staza se, pored navedenog, u obzir mora uzeti i atraktivnost i bezbednost okruženja za koje se planira biciklistički saobraćaj, jer biciklisti voze na otvorenom (omogućiti atraktivnost i prijatnost vožnje biciklom, voditi računa o fizičkim i psihičkim sposobnostima biciklista). Biciklisti se svrstavaju u spori saobraćaj, dok u gradovima prevoz biciklom predstavlja jedan od najbržih oblika prevoza. Najvažniji elementi analize prilikom projektovanja biciklističkih površina obuhvataju: bezbednost saobraćajne površine, povezanost biciklističke mreže (bez prekida, dobre veze sa ostatkom saobraćajne mreže, mogućnost vraćanja na polaznu tačku putovanja), atraktivna i za biciklistu privlačna rešenja, udobnost saobraćajnih površina, blizina puta, odmorišta, vegetacije i sl. Poprečni profil koji predstavlja polaznu projekciju prilikom projektovanja i stvaranja budućeg saobraćajnog prostora se sastoji od više elemenata, od kojih su osnovni kolovozne i razdelne trake. Među kolovozne trake se ubrajaju i trake za biciklistički saobraćaj koje se mogu podeliti na biciklističke trake i biciklističke staze. Tretman biciklista u poprečnom profilu može biti rešen na jedan od sledećih načina:

- Biciklisti mogu da dele kolovoznu površinu sa ostalim vozilima, ali se u takvim slučajevima za vođenje biciklističkog saobraćaja koji se odvija na kolovozu zajedno sa motornim saobraćajem, uz korišćenje propisne saobraćajne signalizacije, biraju putevi sa nižom frekvencijom saobraćaja motornih vozila, a to su pristupne ulice i u posebnim slučajevima sabirne ulice. Ono što se može izdvojiti kao prednost ovakvog tretmana biciklista je: nema potrebe za dodatnim površinama, biciklisti zadržavaju potpunu slobodu kretanja, prostorno i finansijski povoljnije rešenje, uspostavljanje koegzistencije u područjima gde se vrši smirivanje saobraćaja, što i jeste cilj saobraćajne politike svih modernih gradova Evrope. Pored prednosti, ovakvo rešenje ima i svoje nedostatke: deonice puteva sa ovakvim profilom su opasnije za bicikliste, parkiranje na ulicama ometa bicikliste, a može biti i opasno (npr. otvorena vrata automobila), biciklisti za motorni saobraćaj predstavljaju prepreku, pogotovo na uskim profilima ulica, biciklisti imaju manje mogućnosti za preticanje;

- Kod slabije opterećenih saobraćajnica postoji mogućnost izdvajanja dela kolovoza uz desnu ivicu koji služi isključivo za kretanje biciklista i tada se formiraju jednosmerne biciklističke trake koje su obeležene posebnom horizontalnom signalizacijom i/ili posebnom bojom kolovozne površine ili drugačijim tipom kolovoznog zastora i nalaze se $u$ istom visinskom nivou kao $i$ kolovoz (Sl. 4). Primena biciklističkih traka je karakteristična za sabirne ulice i u posebnim slučajevima gradske magistrale;

- Treći način formiranja površina za kretanje biciklista podrazumeva potpuno fizičko odvajanje od protočnog saobraćaja sa formiranjem jedno- ili dvosmernih biciklističkih staza koje ne moraju biti u istom nivou sa kolovozom (Sl. 5). Njihova primena je karakteristična za gradske magistrale. Biciklističke staze se mogu projektovati kao prostorno nezavisni potezi kada se formiraju deonice nezavisne mreže za biciklistički saobraćaj. Ukoliko je vršno časovno opterećenje 
biciklista i pešaka malo mogu se predvideti jedinstvene kolovozne površine, odnosno biciklističko-pešačke staze.
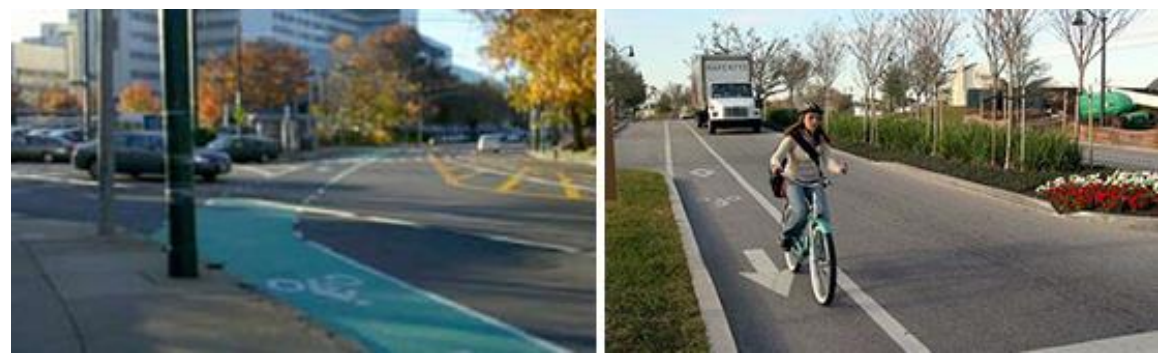

Slika 4. Primeri biciklističke trake u poprečnom profilu gradske saobraćajnice [7]

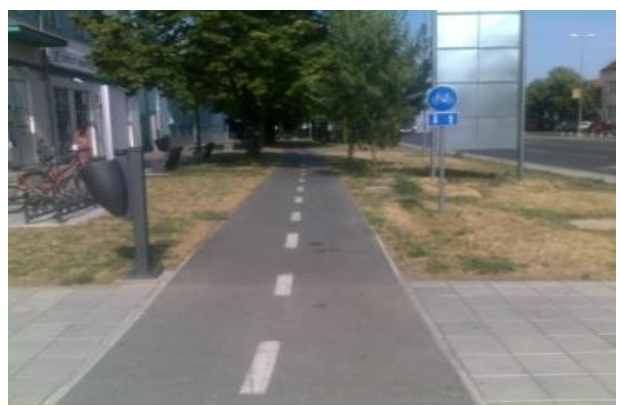

Slika 5. Biciklistička staza u Staroj Pazovi

Kod saobraćajnog profila za bicikliste ne postoji uslov internog razmaka budući da jedinični saobraćajni profil već sadrži određene rezerve u poprečnom smislu, a i kretanje se odvija pri niskim brzinama. Ipak moraju postojati zaštitni razmaci na spoljnim granicama združenih saobraćajnih profila gde se ostvaruje kontakt sa ivičnim sadržajima i/ili drugim vidovima prevoza, uključujući i zaštitni razmak između pešaka i biciklista.

Za dvosmerni saobraćaj se primenjuju samostalni biciklistički putevi. Jedan biciklistički modul je moguće primeniti ako su mala opterećenja biciklista i pešaka i ako je biciklistička staza postavljena na istoj visini kao i pešačka kada se mimoilaženje i preticanje obavlja korišćenjem pešačke staze. Profil samostalne biciklističke staze sadrži dva biciklistička modula, a slobodni profil je uvećan za $0,25 \mathrm{~m}$ u odnosu na saobraćajni. Tri ili više biciklističkih modula se primenjuju samo na osnovu rezultata provere zahtevanog nivoa usluge za merodavno opterećenje biciklista $[4,5,7]$.

Biciklističke trake [1,2,9] se projektuju kao sastavni deo protočnog kolovoza na saobraćajnicama manjeg značaja i one su sastavni deo kolovoznog profila sa jedinstvenom visinom saobraćajnog $(4,20 \mathrm{~m})$ i slobodnog profila $(4,50-4,70 \mathrm{~m})$. Izvode se u ravni kolovoza, a izdvajaju horizontalnom signalizacijom i/ili drugačijom bojom ili vrstom kolovozne površine. Biciklističke trake u naselju su, po pravilu, dvostrane i jednosmerne, dok se biciklističke trake izvan naselja ne preporučuju iz saobraćajno-bezbednosnih razloga. Biciklističke trake se mogu voditi i u profilima gde je organizovano podužno parkiranje putničkih automobila. I u ovom slučaju su sastavni deo kolovoznog profila. Ono što bi posebno trebalo naglasiti jeste da je primena biciklističkih traka veoma problematična na potezima na kojima postoji autobuski saobraćaj, naročito u području 
stanica javnog gradskog prevoza. Takođe, u zonama gde se parkiranje odvija izvan kolovoza, primena biciklističkih traka je dosta nepovoljna, jer se manevar ulaska/izlaska $\mathrm{u} / \mathrm{sa}$ parking prostora odvija preko biciklističkih traka uz veoma otežane uslove preglednosti. U ovakvim uslovima se preporučuje primena izdvojenih biciklističkih staza. Biciklističke staze $[1,2,9]$ su samostalni putevi koji se rade u regulacionom pojasu gradskih saobraćajnica i na njima se može odvijati dvosmerno kretanje biciklista. Od kolovoza za protočni saobraćaj mogu biti odvojene visinski (ivičnjak) i situaciono (zaštitni razmak ili ivična razdelna traka). Mešovite staze za bicikliste i pešake se ne preporučuju i treba ih koristiti samo u slučajevima kada nema dovoljno prostora za samostalno izvođenje pešačke i biciklističke staze. Biciklističke staze su pogodnije za naseljena mesta, dok se izvan naselja preporučuje izgradnja biciklističkih puteva. U zonama stanica javnog gradskog prevoza biciklističke staze se vode iza perona, odnosno nadstrešnice. Prednosti koje se postižu primenom biciklističkih staza su: veća bezbednost biciklista, veći komfor za bicikliste, lakše međusobno preticanje biciklista. Međutim biciklističke staze mogu imati i nedostatke, kao što su: veća brzina kretanja svih učesnika u saobraćaju, zauzimanje veće/šire površine, mogućnost saobraćajnih udesa, pogotovo na raskrsnicama ili kod vožnje u pogrešnom smeru ili pogrešnom stranom, veći finansijski troškovi. Prilikom projektovanja biciklističkih staza je neophodno definisati elemente situacionog i nivelacionog plana. Za definisanje graničnih elemenata situacionog i nivelacionog plana se primenjuju merodavni parametri koji predstavljaju osnovu njihovog definisanja. Neki od merodavnih parametra koji su vezani za biciklistički saobraćaj, a koje je neophodno definisati kao ulazne elemente prilikom projektovanja su: parametri vozila, poprečni nagib kolovoza, kružne krivine, podužni nagib i vertikalne krivine. Kod projektovanja biciklističkih površina treba voditi računa o njihovim ukrštanjima sa drugim saobraćajnim površinama, jer se većina saobraćajnih udesa u kojima učestvuju biciklisti dogodi na raskrsnicama. Takođe, radi što intenzivnijeg korišćenja bicikla kao prevoznog sredstva u urbanim sredinama, potrebno je obezbediti uređena i sigurna parkirališta, kao što su različiti sistemi postolja za kratkotrajno, odnosno parkirališta i objekti/biciklarnice za dugotrajno parkiranje bicikala.

\section{PREDLOG KONCEPTA BICIKLISTIČKIH STAZA U BANOVCIMA}

Stari i Novi Banovci su naselja koja pripadaju opštini Stara Pazova, a zajedno sa naseljem Banovci Dunav čine jednu celinu poznatu kao Banovci. Banovci su linearno naselje, duž desne obale Dunava, mesto porodičnih kuća. Nalaze se na istoku opštine i sa svojim odličnim geografskim položajem predstavljaju veoma povoljno mesto za život. Upravo zbog navedenih karakteristika lokacija Banovaca je odabrana kao karakterističan reprezent vojvođanskog okruženja za koncipiranje rešenja biciklističkog saobraćaja u urbanim sredinama koje već imaju određenu tradiciju u smislu biciklističkih kretanja.

Naselje Banovci se prostire između dva značajna saobraćajna pravca-evropskog i magistralnog, što ovom naselju daje izuzetno povoljan geo-saobraćajni položaj. Čitavom svojom istočnom stranom naselje se oslanja na obalu Dunava i to u dužini od oko $7,5 \mathrm{~km}$. Sa saobraćajnim kapacitetima višeg hijerarhijskog nivoa-državnim putem IA reda (E-75) naselje je povezano mrežom opštinskih puteva, i to preko dve petlje. Osnovnu saobraćajnu mrežu u naselju čine sledeće kategorije ulica [8]:

- glavna naseljska saobraćajnica; 
- sabirne naseljske saobraćajnice;

- ostale naseljske saobraćajnice-ulice.

Uzimajući u obzir geomorfološke karakteristike terena (Banovci, kao sva druga naselja opštine Stara Pazova, su naselja ravničarskog tipa) i zbog malih udaljenosti, naselje Banovci ima veoma dobre prostorne mogućnosti za razvoj biciklističkog saobraćaja.

Prostorne mogućnosti, odnosno kapaciteti za izgradnju biciklističkih staza u naseljima Stari i Novi Banovci su usko vezani sa tipologijom ulica. Na osnovu analize stanja na terenu, uslova, kao i parametara datih Planom generalne regulacije naselja Banovci [8], definisane su sledeće ulice u kojima postoji mogućnost izgradnje biciklističkih staza:

- glavne naseljske saobraćajnice: Braće Trninić, Pavla Šašića, Zdravka Jekića, Pere Čodanovića, Milenka Pevca i Svetosavska;

- sabirne naseljske saobraćajnice: Železnička, Fruškogorska i Zemunska.

Ostale naseljske saobraćajnice nemaju dovoljno širok koridor da bi se mogao obezbediti prostor za individualnu biciklističku stazu.

$\mathrm{Na}$ osnovu analize raspoloživog prostora unutar koridora ovih saobraćajnica, trake za biciklistički saobraćaj se mogu predvideti kao samostalne dvosmerne biciklističke staze u regulacionom pojasu naseljskih saobraćajnica Starih i Novih Banovaca. Konceptom rešenja biciklističkih staza za pomenuta naselja je planirano da biciklističke staze prate najuticajnije pravce kretanja drumskog saobraćaja unutar naselja i na taj način omoguće dolazak biciklom do glavnih sadržaja javnih i društvenih namena (dom zdravlja, škola, dečije ustanove, park i sl.). Osim toga ovim rešenjem se obezbeđuje povezanost naselja Banovci sa susednim naseljima opštine (Stara Pazova, Nova Pazova i Belegiš), jer postoji potreba za vannaseljskim kretanjima radi sadržaja koji se ne nalaze u samim Banovcima, U današnjim uslovima, zbog malih udaljenosti između naselja, veliki broj kretanja se već obavlja biciklom. Kao razlozi koji prouzrokuju potrebe za vannaseljskim kretanjima se mogu navesti radne zone koje se nalaze na rubovima spomenutih naselja, kao i kreiranje novih sadržaja (npr. opštinski bazeni) koji privlače veliki broj korisnika, a izgrađeni su između naselja na približno jednakim rastojanjima. Iz tih razloga u ulicama Zdravka Jekića, Pere Čodanovića i Braće Trninić, koje su ujedno i glavne naseljske saobraćajnice i njihove trase se poklapaju sa mrežom opštinskih puteva, biciklističke staze su planirane do granice naselja kako bi se omogućio kvalitet, viši nivo bezbednosti i bolja povezanost biciklističkog saobraćaja između naselja i zadovoljile sve potrebe učesnika. Fruškogorska ulica, koja je po svom rangu sabirna naseljska saobraćajnica, je predviđena kao veza tri opštinska puta unutar naselja, a samim tim bi i planirana biciklistička staza koja bi egzistirala njenom dužinom predstavljala vezu za biciklistički saobraćaj koji će se odvijati unutar naselja. Takođe, prema Planu generalne regulacije naselja Banovci [8], predviđeno je da duž glavnih naseljskih saobraćajnica (ulice Braće Trninić, Pavla Šašića, Milenka Pevca i Svetosavska) bude izgrađena biciklistička staza međunarodnog karaktera, kao deo međunarodne mreže EuroVelo ruta (koridor EuroVelo 6), pa je samim tim potrebno obezbediti vezu ove međunarodne rute sa planiranim naseljskim biciklističkim stazama. Ova ruta je od posebnog značaja, jer će osim za rekreaciju lokalnog stanovništa doprineti i razvoju turističke ponude opštine Stara Pazova, pa i samih Banovaca, u vidu razvoja cikloturizma.

Prema dimenzijama merodavnog vozila je usvojena staza širine 2,50 m. Biciklističke staze su predviđene između kolovoza za protočni saobraćaj i pešačkih staza, ali su širokim ivičnim zelenim pojasom odvojene od motornog saobraćaja. Istovremeno, postoji zelena površina i između pešačke i biciklističke staze (Sl. 6). U početnoj fazi istraživanja je

108 | JOURNAL OF FACULTY OF CIVIL ENGINEERING 28 (2015) | 
predviđeno da se biciklističke staze postave samo sa jedne strane poprečnog profila ulica, jer se smatra da veća ponuda ne bi bila ekonomski opravdana za jedan duži period. Međutim, kapaciteti se veoma jednostavno mogu uvećati imajući u vidu dovoljne rezerve unutar poprečnog profila.

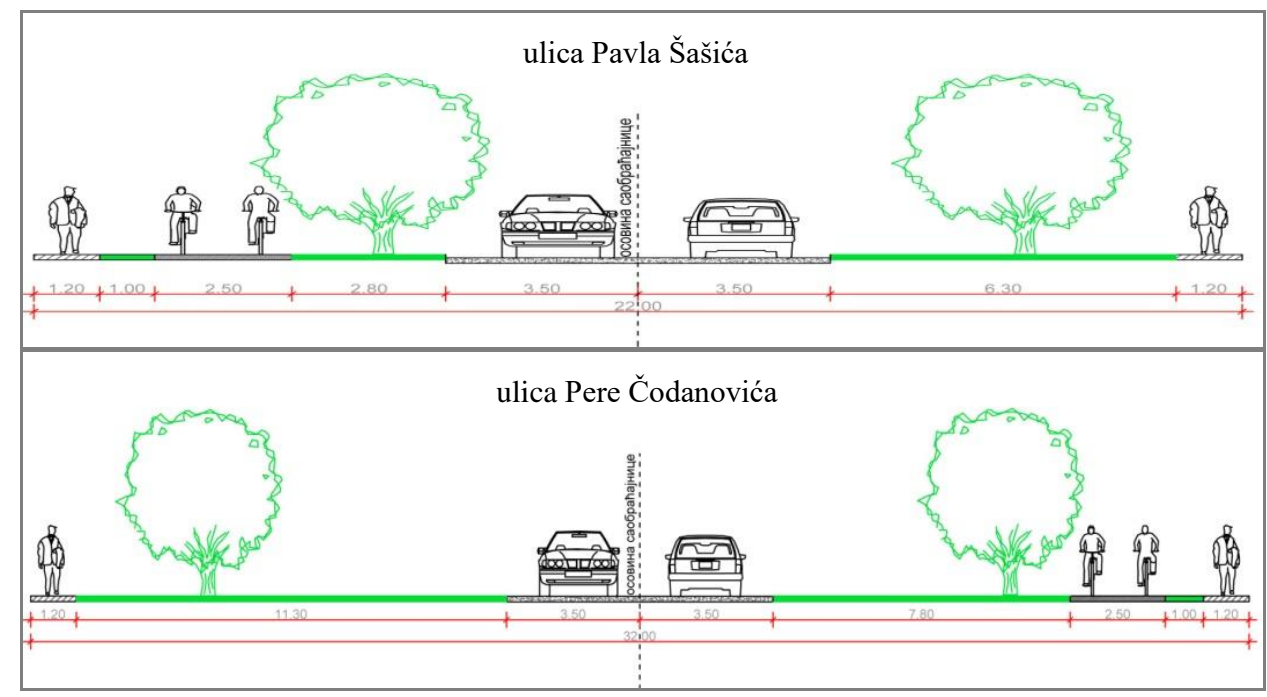

Slika 6. Primer geometrijskih poprečnih profila ulica sa predviđenim biciklističkim stazama

Osnovni krak biciklističke staze (Sl. 7) je projektovan tako da kreće od severa naselja ka centru, duž ulica Braće Trninić i Pavla Šašića, zatim nastavlja ka Novim Banovcima, u pravcu juga, duž ulica Milenka Pevca i Svetosavske ulice, sve do postojeće petlje koja se nalazi na spoju državnog puta IA reda (E-75) i opštinskog puta Stari Banovci-Novi Banovci-Batajnica. Na raskrsnici ulica Pavla Šašića, Pere Čodanovića, Zdravka Jekića i Svetosavske, deo trase se odvaja ka ulici Zdravka Jekića u pravcu naselja Stara Pazova, a deo trase ka ulici Pere Čodanovića i ulicom koja vodi u pravcu naselja Nova Pazova. Jedna od grana trase se pruža Železničkom ulicom od raskrsnice sa Svetosavskom ulicom. Na raskrsnici Svetosavske, Pinkijeve, Grobljanske i Zemunske ulice, deo trase se odvaja u pravcu Zemunske ulice.

Procenjena visina potrebne investicije za izgradnju biciklističkih staza iznosi oko 1,5 milion EUR (Tabela 1) i smatra se da je ovu investiciju moguće mobilisati fazno, $\mathrm{u}$ periodu od 2-3 godine, pri čemu bi dinamika realizacije mogla da obuhvati sledeće faze:

- I faza izgradnje biciklističkih staza bi obuhvatila osnovni krak odnosno biciklističke staze u ulicama Braće Trninić, Pavla Šašića, Milenka Pevca i Svetosavska, koje su planirane kao deo međunarodnog biciklističkog koridora EuroVelo 6;

- II faza izgradnje biciklističkih staza bi se ostvarila realizacijom biciklističkih staza duž ulica Zdravka Jekića, Pere Čodanovića, Železničkoj, Fruškogorskoj i Zemunska, koje bi zadovoljile potrebe za biciklističkim kretanjem unutar naselja;

- III faza izgradnje biciklističkih staza uzima u obzir planirane veza između naselja Banovci i naselja Stara Pazova, Nova Pazova i Belegiš i na taj način bi bile obezbeđene potrebe za vannaseljskim kretanjima. 


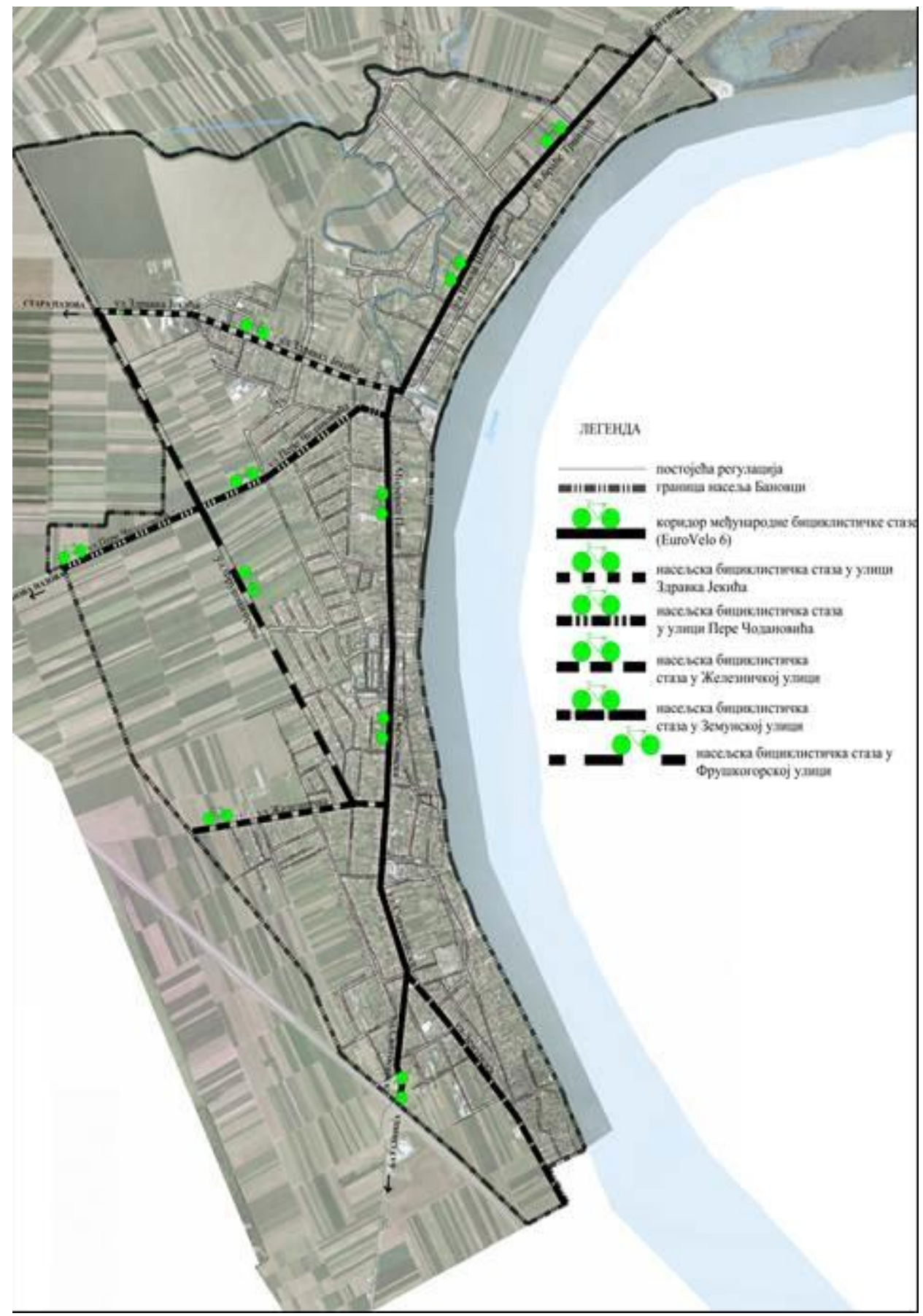

Slika 7. Pregledna karta planiranih biciklističkih staza 
Tabela 1. Planirane dužine i generalna procena potrebnih finansijskih sredstava za realizaciju koncepta

\begin{tabular}{|c|l|c|r|}
\hline r.br. & \multicolumn{1}{|c|}{ naziv ulice } & dužina staze $[\mathrm{m}]$ & \multicolumn{1}{|c|}{ procena vrednosti $[€]$} \\
\hline 1. & Braće Trninić & 1.614 & 142.274 \\
\hline 2. & Pavla Šašića & 1.109 & 97.759 \\
\hline 3. & Zdravka Jekića & 1.977 & 174.273 \\
\hline 4. & Pere Čodanovića & 2.343 & 206.535 \\
\hline 5. & Milenka Pevca & 1.797 & 158.406 \\
\hline 6. & Svetosavska & 2.290 & 201.864 \\
\hline 7. & Železnička & 1.290 & 113.714 \\
\hline 8. & Fruškogorska & 3.369 & 296.977 \\
\hline 9. & Zemunska & 1.725 & 152.059 \\
\hline \multicolumn{2}{r}{ ukupno } & 17.514 & 1.543 .861 \\
\hline
\end{tabular}

\section{ZAKLJUČAK}

Efekti izgradnje biciklističkih površina su višestruki. Opšte poboljšanje kvaliteta života u gradovima, uz manje zagađenje vazduha, manje buke, uštede prostora na putevima i parkiralištima, a time i smanjenje ulaganja u saobraćajnice uz mogućnost drugačijeg korišćenja javnog prostora, samo su neke od prednosti biciklističkog saobraćaja. Povećanjem učešća biciklističkog saobraćaja u opštem saobraćajnom sistemu se ostvaruju različite koristi, poput ekonomskih, socijalnih i ekoloških. Biciklizam je najbrži način prevoza u gradovima na udaljenostima do $5 \mathrm{~km}$, energetski efikasan, prva je alternativa motornom saobraćaju i zato mora biti uzet u obzir na svim nivoima planiranja od razvoja gradova i novih mesta do relativno malih infrastrukturnih intervencija.

Biciklistička staza je najkvalitetnije infrastrukturno rešenje za bicikliste, budući da ih fizički odvaja od ostatka saobraćaja. Potrebna je na prometnim i vrlo brzim putevima i gradskim saobraćajnicama, na frekventnim biciklističkim tokovima, ali i u rekreativnim biciklističkim mrežama, koje su često nezavisne od tokova motornog saobraćaja.

U radu su prikazani osnovni uslovi i parametri potrebni za planiranje i projektovanje biciklističkog saobraćaja u urbanim sredinama, te isti primenjeni na nivou opšte studije na primeru naselja Stari i Novi Banovci. Posebno se ističe potreba tretmana biciklističkog saobraćaja u okviru izrade planske dokumentacije radi stvaranja osnove za kvalitetno rešenje biciklističkog saobraćaja i uređenje biciklističkih površina u urbanim sredinama, pri čemu se moraju ispuniti svi programsko-projektni uslovi koji bi kasnije doveli i do odgovarajuće, ekonomski opravdane i bezbedne realizacije investicije.

\section{LITERATURA}

[1] Tehnička uputstva za projektovanje saobraćajnica u gradovima, predlog, Institut za saobraćajnice i geotehniku, Građevinski fakultet Univerziteta u Beogradu, Beograd, 2008. 
[2] Maletin, M., Planiranje i projektovanje saobraćajnica u gradovima, Orion-art, Beograd, 2009.

[3] Veselinović M., Studija biciklističkog saobraćaja za grad Banja Luku, Banja Luka, 2009.

[4] Saobraćajna studija grada Novog Sada sa dinamikom uređenja saobraćaja-Nostram, JP Urbanizam, Zavod za urbanizam Novi Sad, Novi Sad, 2009.

[5] Đordaš, M. i dr., Studija biciklističkih staza u gradu Bjelovaru, APE d.o.o. za arhitekturu, planiranje i ostale poslovne delatnosti, Zagreb, 2010.

[6] Kresonja, J., Biciklistički priručnik, Zagreb, 2011.

[7] Urban Bikeway Design Guide, National Association of City Transportation Officials, USA, 2011.

[8] Plan generalne regulacije naselja Banovci (Stari Banovci, Novi Banovci, Banovci Dunav), Službeni list opština Srema, br. 2/2010, 17/2012.

[9] Priručnik za projektovanje puteva u Republici Srbiji, JP Putevi Srbije, Beograd, 2012.

[10] Estimating Bicyling and Walking for Planning and Project Development: A Guidebook, Transportation Research Board, 2014.

[11] Basarić, V., Nemotorizovani i stacionarni saobraćaj, izvod iz predavanja, II dio, Univerzitet Aperion, Saobraćajni fakultet, Banja Luka, 2015.

[12] Pedestrian and Bicycle Transportation along Existing Roads-Active-Trans Priority, Tool Guidebook, Transportation Research Board, 2015.

\section{BICYCLE TRAFFIC IN URBAN AREAS}

Summary: Cycling is a term describing the use of bicycles, but also any mean of transport driven solely by human power. Development of bicycle traffic in urban areas involves construction of cycling infrastructure, adapting streets and other traffic infrastructure to a form suitable for cycling and other means of transport (individual motorized traffic, public transport, walking), ensuring the adequate budget and systematic planning and development of sustainable transport in cities. The paper presents basic settings and conditions as input elements to plan bicycle traffic in urban areas, as well as programdesign conditions which lead the activities of planners and designers of urban roads in connection with cyclists.

Keywords: traffic, cycling, planning, program-design conditions, public transport 